\title{
Are courses chosen to reduce skill-deficiencies? an experimental approach
}

Citation for published version (APA):

Borghans, L., \& Golsteyn, B. H. H. (2007). Are courses chosen to reduce skill-deficiencies? an experimental approach. Researchcentrum voor Onderwijs en Arbeidsmarkt, Faculteit der Economische Wetenschappen. ROA Research Memoranda No. 1 https://doi.org/10.26481/umaror.2007001

Document status and date:

Published: 01/01/2007

DOI:

10.26481/umaror.2007001

Document Version:

Publisher's PDF, also known as Version of record

\section{Please check the document version of this publication:}

- A submitted manuscript is the version of the article upon submission and before peer-review. There can be important differences between the submitted version and the official published version of record.

People interested in the research are advised to contact the author for the final version of the publication, or visit the DOI to the publisher's website.

- The final author version and the galley proof are versions of the publication after peer review.

- The final published version features the final layout of the paper including the volume, issue and page numbers.

Link to publication

\footnotetext{
General rights rights.

- You may freely distribute the URL identifying the publication in the public portal. please follow below link for the End User Agreement:

www.umlib.nl/taverne-license

Take down policy

If you believe that this document breaches copyright please contact us at:

repository@maastrichtuniversity.nl

providing details and we will investigate your claim.
}

Copyright and moral rights for the publications made accessible in the public portal are retained by the authors and/or other copyright owners and it is a condition of accessing publications that users recognise and abide by the legal requirements associated with these

- Users may download and print one copy of any publication from the public portal for the purpose of private study or research.

- You may not further distribute the material or use it for any profit-making activity or commercial gain

If the publication is distributed under the terms of Article $25 \mathrm{fa}$ of the Dutch Copyright Act, indicated by the "Taverne" license above, 


\title{
Are Courses Chosen to Reduce Skill- Deficiencies? An Experimental Approach
}

\author{
Lex Borghans \\ Bart H.H. Golsteyn
}

ROA-RM-2007/1
May 07

Research Centre for Education

and the Labour Market

P.O. Box 616

6200 MD Maastricht

The Netherlands

E-mail: $\quad$ mailto:secretary@ @roa.unimaas.nl

Internet: http://www.roa.unimaas.nl

Maastricht University

Faculty of Economics and Business Administration 
The ROA Research Memorandum Series was created in order to make research results available for discussion, before those results are submitted for publication in journals. 
ROA-RM-2007/1 » http://www.roa.unimaas.nl/resmem.htm

\section{Abstract \\ Are Courses Chosen to Reduce Skill-Deficiencies? An Experimental Approach $^{1}$}

Do people choose courses to reduce work-related skill-deficiencies, and do they choose courses deliberately? We measure the skill-deficiency for six skills and perform an experiment in which workers are offered three courses related to these skills. They may exchange these courses for other courses. Randomizing the default package of courses, we identify the deliberateness of their choice. We find that people choose the default courses more often, especially when these match their skill-deficiencies. When workers make their own choice however, they generally do not choose courses with which they can reduce their skill-shortages. We relate choice behavior to personal characteristics.

JEL Codes: J24, J31, I2

Keywords: Human capital investment, Training, Default

Lex Borghans

Department of Economics and ROA

P.O. Box 616

6200 MD Maastricht

mailto:l.borghans@ roa.unimaas.nl
Bart Golsteyn

ROA

P.O. Box 616

6200 MD Maastricht

mailto:b.golsteyn@roa.unimaas.nl

1. The authors thank Tim Barmby, Arnaud Dupuy, Rachel Griffith, Hans Heijke, David Huffman, Moshe Hazan, Huub Meijers, Markus Mobius, Bas ter Weel and seminar participants at Maastricht University, the 2005 NAKE day, IZA and the 2006 SOLE conference for valuable comments. 



\section{Introduction}

How do workers act in situations where they are offered courses to reduce on-the-job skill-deficiencies? In particular, do people choose courses to reduce work-related skilldeficiencies, and do they choose courses deliberately? Which personal characteristics determine the outcome of these choices? The aim of this research is to analyze these questions using an experimental approach in which we ask workers to choose courses from a fixed set of options. The main advantage of the experiment is that we avoid the usual endogeneity problems concerning the decision to participate in training.

We ask 1,631 young workers to consider a situation in which they are offered by their firm a package of three training courses. They can choose to accept these courses or to exchange them for courses from a menu of three alternatives. The set of courses they have to pick three options from, are courses in a foreign language (English), Management, Stress management, Team work, Computer skills and Efficient working. From an earlier survey we have collected information about the perceived skill-deficiencies of the subjects in fields related to the courses offered.

The idea is that people consider the default option as an implicit advise about what is a reasonable choice. The combination of randomized default packages and survey information about perceived deficiencies, allows us to identify how the actual choices are related to this implicit advise and to perceptions about the usefulness of the courses in the mind of the respondent. First, we find that workers on average have a strong propensity to choose the default courses. Hence, many workers do not seem to make a deliberate choice. Second, we find that the probability to accept the default is related to the skill-deficiency of the respondent in the field of the training that is offered. A default offer therefore seems to reinforce the individual perception of skill-needs. Third, we find however that when workers choose their own courses from the menu, they do not choose courses with which they can reduce skill-shortages. Relating choice behavior to personal characteristics, we find, fourthly, evidence that workers who have a more developed capacity to imagine the future invest more in their skill-deficiencies. Better imagination also increases the probability of making a deliberate choice. We find that lower anxiety, lower risk aversion, and more cognitive skills also increase the probability of a deliberate choice, but these attributes are not related with investments in the skill-needs of the respondent.

The analysis of the effect of training on the reduction of on-the-job skill-deficiencies is 
related to the effects of training on productivity and wages as discussed by among many others Conti (2005) and Parent (1999). Frazis and Loewenstein (2005) show that the returns to training are very heterogeneous. We argue that differences in the effective choice of courses - related to both personal characteristics and environmental circumstances can contribute to this heterogeneity. We argue that individuals differ in their interest and ability to choose courses and that individual attributes determine the return on the investment in training. Therefore, this essay contributes also to the literature on the effect of non-cognitive skills on labor market outcomes (Mueser 1979, Bowles, Gintes, and Osborne 2001, Heckman, Stixrud, and Urzua 2006).

Other authors have investigated the discriminatory factors that determine whether or not people participate in courses. Shields (1998) shows that participation in training differs substantially between workers. Colquitt, LePine, and Noe (2000) show that psychological factors such as anxiety influence to a large extent whether people invest in human capital and Eraut (2000) shows that self-confidence is an important factor that stimulates course participation at work. E.g. Field (2000) and Sargant and Aldridge (2002) have pointed out that course participation crucially depends on whether people face impediments or stimuli to participate. Such impediments may be of practical or financial nature. This essay adds to this literature that stimulating training participation does not necessarily imply that people will choose the most profitable courses.

The analysis is also related to literature about choosing when faced with defaults options. In recent literature the idea that defaults may influence decisions is used in analyses related to organ donation decisions (Johnson and Goldstein 2003, Abadie and Gay 2006), car insurances (Johnson, Hershey, Meszaros, and Kunreuther 1993), car purchases (Park, Yun, and MacInnis 2000), consent with e-mail marketing (Johnson, Bellman, and Lohnse 2002) and pensions with 401(k) saving (Choi, Laibson, Madrian, and Metrick 2005), yet no attempt has thus far been made to introduce this notion in the human capital literature.

Section 2 is concerned with a description of the data and the set-up of the experiment. Section 3 discusses the estimation method. Section 4 reports the results. Section 5 shows additional tests and section 6 concludes. 


\section{Data and the experiment}

We use two Dutch data sets. The first is the Fall 2004 Research Centre for Education and the Labour Market Schoolleaver Survey. We measured the skill-deficiency of the respondents in this survey. In the second survey which was held in the spring of 2005 we approached the same respondents again and asked them to participate in an experiment.

\subsection{Skill-deficiency}

In the 2004 survey, workers are interviewed 1.5 years after they graduated from professional college ("Hoger Beroepsonderwijs (HBO)") or university. Some of the graduates followed their education at a later age. We selected young workers in the age below 35 years of age.

The respondents are asked to indicate the level of their skills with respect to a comprehensive set of aspects. In addition they are asked which level of skills is required in their jobs with respect to these aspects. We use the difference between the skills a person indicates to be required for the job and the skills he indicates to posses as a measure for the skill-deficiency. Table 1 gives the exact wording of the question and indicates the 6 skills we will use to analyze our hypotheses: working well under pressure; applying ICT; communicating in foreign languages; drawing on other people's capabilities; working productively with other people; and working in accordance with a budget.

We are interested in the propensity of respondents to choose courses related to their skill-deficiency. If the measure is negative or zero, a person has no skill-deficiency. We recoded negative values of the measure to zero. ${ }^{1}$ We find that $55.3 \%$ of the respondents have skill-deficiencies regarding at least one of the selected skills.

\subsection{The experiment}

To avoid the risk of respondents checking their choices with the level of the skill-deficiency for internal consistency, we approached the respondents of the 2004 survey again in the spring of 2005. Respondents were approached by e-mail to fill out a questionnaire on the internet called "Dealing with difficult choices." In the mail, we explained that the aim of the research is to increase understanding of how young people deal with difficult

\footnotetext{
${ }^{1}$ In the robustness analysis, we show that if we would not recode the negative values, the results remain similar.
} 
Table 1: Skill-deficiency question

\begin{tabular}{|c|c|c|}
\hline $\begin{array}{l}\text { Below are aspects that could be of importance in your job. } \\
\text { Rate for each of these aspects: }\end{array}$ & $\begin{array}{l}\text { The required level } \\
\text { in your job } \\
\text { Average }<->\text { Excellent }\end{array}$ & $\begin{array}{c}\text { Your own level } \\
\text { Average }<->\text { Excellent }\end{array}$ \\
\hline $\begin{array}{l}\text { Working well under pressure } \\
\text { Applying ICT } \\
\text { Communicating in foreign languages } \\
\text { Drawing on other people's capabilities } \\
\text { Working productively with other people } \\
\text { Working in accordance with budget, planning or guidelines }\end{array}$ & $\begin{array}{lllll}1 & 2 & 3 & 4 & 5 \\
1 & 2 & 3 & 4 & 5 \\
1 & 2 & 3 & 4 & 5 \\
1 & 2 & 3 & 4 & 5 \\
1 & 2 & 3 & 4 & 5 \\
1 & 2 & 3 & 4 & 5\end{array}$ & $\begin{array}{lllll}1 & 2 & 3 & 4 & 5 \\
1 & 2 & 3 & 4 & 5 \\
1 & 2 & 3 & 4 & 5 \\
1 & 2 & 3 & 4 & 5 \\
1 & 2 & 3 & 4 & 5 \\
1 & 2 & 3 & 4 & 5\end{array}$ \\
\hline
\end{tabular}

Source: Research Centre for Education and the Labour Market 2004 Graduate Survey.

decisions, especially those related to educational choices. We explained that knowledge about these processes is of great societal and scientific importance since e.g. $20 \%$ of all graduates indicate that they regret their educational choice. To stimulate participation and deliberate answers, we offered the respondents upon completion of the questionnaire a profile about their personal style to deal with choices.

In the survey, we made a hypothetical offer of courses with an experimental setup to 1,631 workers with a high probability to stay in their current jobs. ${ }^{2}$ We employ this experiment to avoid endogeneity in opportunities to participate in training and to randomize the offer of courses. The hypothetical nature of the experiment is chosen because knowledge about behavioral aspects of participation in education and training is still limited. Therefore we want to explore the mechanisms before doing field experiments.

In the experiment we offered courses related to the 2004 list of aspects. The skills asked in the 2004 survey often were too general in nature to offer as a course to the graduates. We therefore translated the general skills into more specific courses. Table 2 shows which course we propose for each skill. Obviously, even more specific courses could be offered. We chose however to leave it to the respondents to imagine which specific course they would take within the courses offered because of the potentially great diversity in the levels of the respondents with respect to the skills and the specific needs.

\footnotetext{
${ }^{2}$ The choice for investing in skill-shortages might be affected by the preference for leaving the current job for another job which requires a different skill mix. To have a homogenous group of respondents, we consider only those who have a high probability to stay in their current jobs. We selected workers based on the question: "How well is your job related to your education?" The answers range from 1. poor, 2. insufficient, 3. sufficient, 4. good. We select the respondents who have a sufficient or good relation between education and their job. $73.7 \%$ of the workers have a job which is sufficient or
} 
Table 2: The specific courses offered related to the skills

\begin{tabular}{l|r}
\hline \hline Skill $^{a}$ & Course $^{b}$ \\
\hline Working well under pressure & Stress Management \\
Applying ICT & Computer \\
Communicating in foreign languages & English \\
Draw on other people's capabilities & Management \\
Working productively with other people & Team Work \\
Working in acc. with budget, planning or directions & Efficient working \\
\hline \hline
\end{tabular}

Source: Research Centre for Education and the Labour Market 2004 Graduate Survey and 2005 supplement.

\footnotetext{
${ }^{a}$ Question asked in the 2004 survey to analyze the required and own level of skills.

${ }^{b}$ Translation of the skill into the specific course offered in the 2005 supplement.
}

The hypothetical offer reads as follows:

Suppose your work has a new settlement in which everyone can participate during working hours in the following courses, the expenses of which are fully covered by the employer: English, Computer skills, Stress Management. However, it is also possible to exchange one or more courses. The alternatives are Management skills, Team work, Efficient working. Do you choose the suggested set of courses or do you want to exchange?

Note that we phrased this question in a way that there are no financial or time-related restrictions to the employee. And the question is constructed such that the courses which are offered in the "default" package, are the courses which the employer suggests to the employees. Thereby an advise or a statement about the most appropriate choice is generated.

To identify the effect of the default, we randomized the offered courses. We offered a first group of respondents courses in English, Stress management and Efficient working, with the alternative choices Computer use, Team working and Management. A second group was offered English, Computer use and Stress management, with the alternatives Efficient working, Team working and Management. And a third group was offered Efficient working, Team working and Management, with the alternatives English, Computer use and Stress management. 
The respondents first had to indicate whether they want to choose the offered package or whether they want to exchange courses. If they want to exchange, they had to indicate which courses to leave out and which to add.

We find that $33.0 \%$ of the respondents takes the default package (i.e. all the courses offered), while the remaining respondents exchange at least one course for another course. Choosing the default saves the respondent some time. One potential critique therefore is that respondents might choose the default to faster complete the survey. We checked whether the default was chosen more often by respondents who took less time to complete the survey. We find however the opposite: respondents who choose the default take on average more time to complete the survey. This might indicate that those who take a lot of time in each question are more hesitant when it comes to choosing. We find this relationship between choosing the default and responding slower in the survey for all 8 parts in the survey. The possibility that people who need more time to answer questions become more easily impatient further on in the survey and might therefore rush through the survey is therefore not supported by the evidence.

Table 3 shows that some courses are more popular than others. English, Computer courses and Team work are selected least often. This is in line with what we expected: respondents have had ample opportunities at school and in college to invest in these skills, so their deficiencies are lowest. The table shows furthermore that most people indicate that they need more skills related to Stress management, Management and Efficient working.

\subsection{Individual attributes}

We relate choice behavior to personal characteristics of the individuals. We analyze the relations of the choices with the following psychological characteristics: time preference, capacity to imagine the future, anxiety and risk aversion. Besides this we will look at the relation with cognitive skills. A comprehensive list of the questions measuring these personal characteristics is shown in table 4 .

People with high time preference (i.e. who value the future less) may weigh the consumption aspect of the course more highly. We expect them therefore to have a lower propensity to choose courses to reduce their skill-deficiencies. Time preference is measured by the question: 
Table 3: The choice of courses, average skill-deficiency per course and the percentage of respondents skill deficient in a course

\begin{tabular}{l|cccc}
\hline \hline & Chooses course (\%) & Average skill-deficiency $^{a}$ & St.Dev. & Deficiency $^{b}(\%)$ \\
\hline English & 38.5 & 0.14 & 0.43 & \\
Efficient work & 72.3 & 0.29 & 0.55 & 23.1 \\
Team work & 47.4 & 0.13 & 0.36 & 11.4 \\
Management & 70.8 & 0.28 & 0.52 & 23.1 \\
Computer & 17.7 & 0.13 & 0.40 & 10.8 \\
Stress Management & 53.3 & 0.28 & 0.53 & 22.9 \\
& & & & \\
\hline \hline
\end{tabular}

Source: Research Centre for Education and the Labour Market 2004 Graduate Survey and 2005 supplement.

Note: The experiment to measure the choice for courses reads as follows: Suppose your work has a new settlement in which everyone can participate during working hours in the following courses, the expenses of which are fully covered by the employer: English, Computer skills, Stress Management. However, it is also possible to exchange one or more courses. The alternatives are Management skills, Team work, Efficient working. Do you choose the suggested set of courses or do you want to exchange? We randomized the offered courses and alternatives. We report in this table which courses are chosen most often.

\footnotetext{
${ }^{a} \mathrm{~A}$ skill-deficiency is defined as the difference between the self-assessed required level of skills on the job and the self-assessed own level of skills. We regarded 6 skills: Working well under pressure, Applying ICT, Communicating in foreign languages, Drawing on other people's capabilities, Working productively with other people, Working in accordance with budget, planning or guide lines. A negative skill-deficiency is recoded to zero.

${ }^{b}$ Percentage of the respondents who are skill deficient.
}

"Suppose you win a 10-day holiday trip worth 2000 euros to an interesting destination. To spread participation, you are asked if you can delay your trip with three years in exchange for a longer vacation. How many days should you be offered in addition to accept the offer in 3 years?"

We find that $97.6 \%$ of the respondents filled out an answer between 0 and 30 days. On average people answered 11.6 days (st.dev. 9.0). This corresponds to a time preference of $27.0 \%{ }^{3}$ Compared with an interest rate at a bank this average time preference is therefore very high. In the literature (Frederick, Loewenstein, and O'Donogue 2002) it is known that the measure of time preference is strongly influenced by anchoring effects but that some people consistently score higher or lower on these measures. We validated the measure for time preference with a measure which is used often in psychology (Rachlin, Raineri, and Cross 1991). The measure uses trade-offs between amounts of money now and amounts of future money to elicit time preference and is significantly correlated with our time preference measure (correlation: 0.156, t-value: 6.741).

\footnotetext{
${ }^{3}$ In the tables, we divide this time preference by 100.
} 
When choosing between courses, it will be important to understand the significance of the investment for the accumulation of human capital. We expect therefore that having a high capacity to imagine the future will be related with investing more in skill-deficiencies. The capacity to imagine the future is measured by 9 statements about the image one has about the future (e.g. "I can imagine well what my next job will look like") and the experiences one has had about the past ("My life is now like I thought it would be 3 years ago"). Cronbach's Alpha equals 0.68.

Colquitt, LePine, and Noe (2000) show that anxiety and risk aversion are important for choosing to participate in training. We will analyze whether these factors are also important for the quality of the choice for courses. Anxiety indicates to what extent people are afraid of things they do not have experience with. We expect those with higher anxiety to choose the default more often. It is measured by 3 statements such as "I often think back about unpleasant experiences." Cronbach's Alpha equals 0.48.

Risk averse people can also be expected to have a higher propensity to choose the default. Risk aversion is measured by offering the respondents one amount of money they can get for sure or a higher amount of money with a chance of getting it and a chance of not getting it. We asked 6 questions in which we varied the amounts of money and the chance of getting the money. To deduce information most efficiently, we used follow-up questions. An example is the question: "What would you choose: 800 Euros, or 50\% chance on nothing, 50\% chance on 2000 Euros?" If the respondent chose 800 Euros, he would get the question: What would you choose: "800 Euros, or 50\% chance on nothing, $50 \%$ chance on 2400 Euros?" A respondent who chose 2000 Euros in the first question would get the question: "What would you choose: 800 Euros, or 50\% chance on nothing, $50 \%$ chance on 1600 Euros?"

We expect that people with more cognitive skills will better understand the significance of the investment, and that they will be more able to choose deliberately. Cognitive skills are measured by 8 questions taken from Frederick (2005). An example of these questions is

"Together, a ball and a cap cost 1.10 Euros. The ball costs 1.00 Euros more than the cap. How much does the cap cost?"

Crohnbach's Alpha equals 0.75 for these questions. Frederick (2005) shows that scores 
on this Cognitive Reflection Test are correlated with SAT-scores and scores on several other IQ tests and with the ability to make choices. We find significant correlations between the average number of correctly answered questions and high school grades for nearly all subjects taught in high school and with the average college grade. This indicates that the measure for cognitive skills plausibly reflects some general type of cognitive skills. 


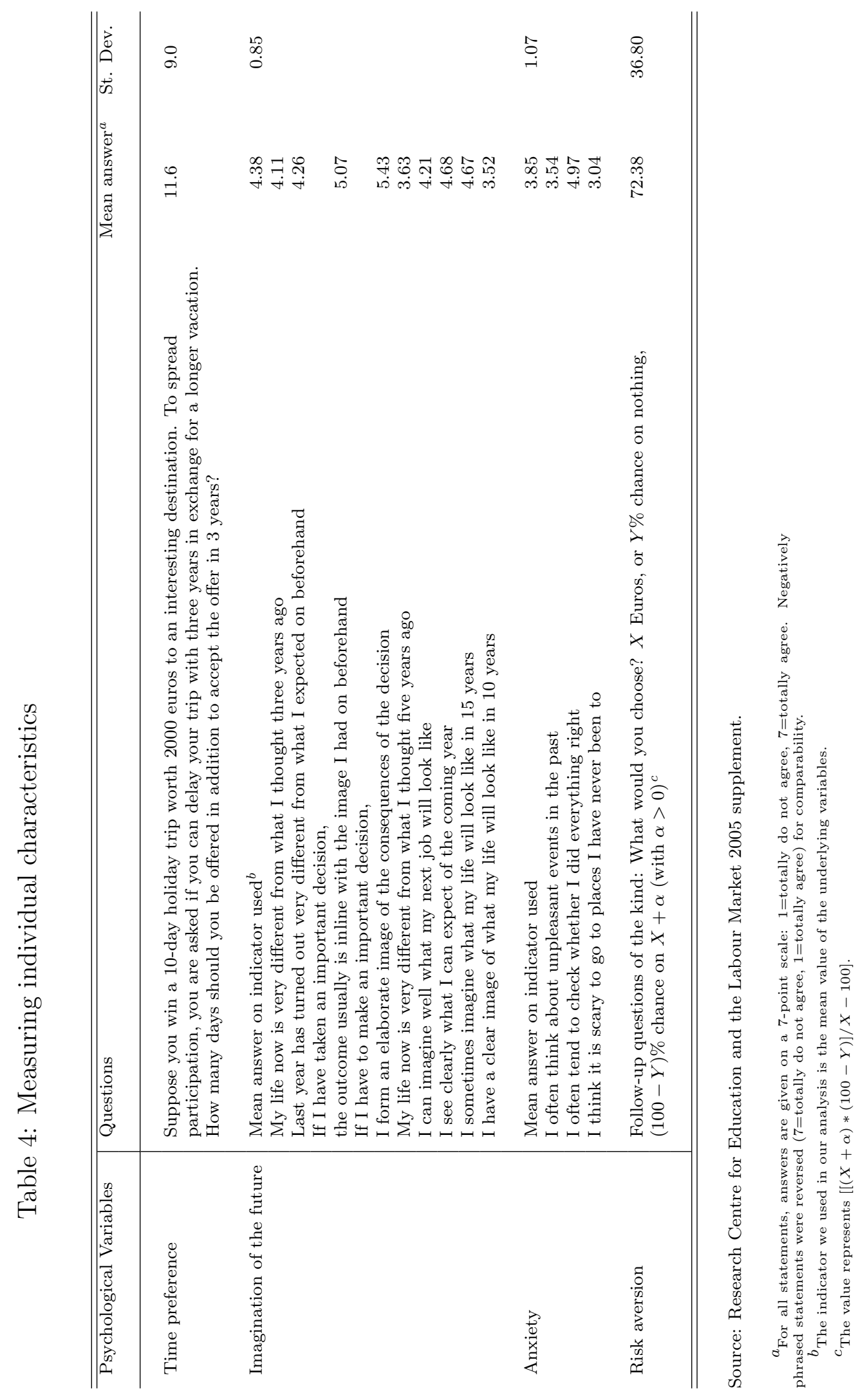




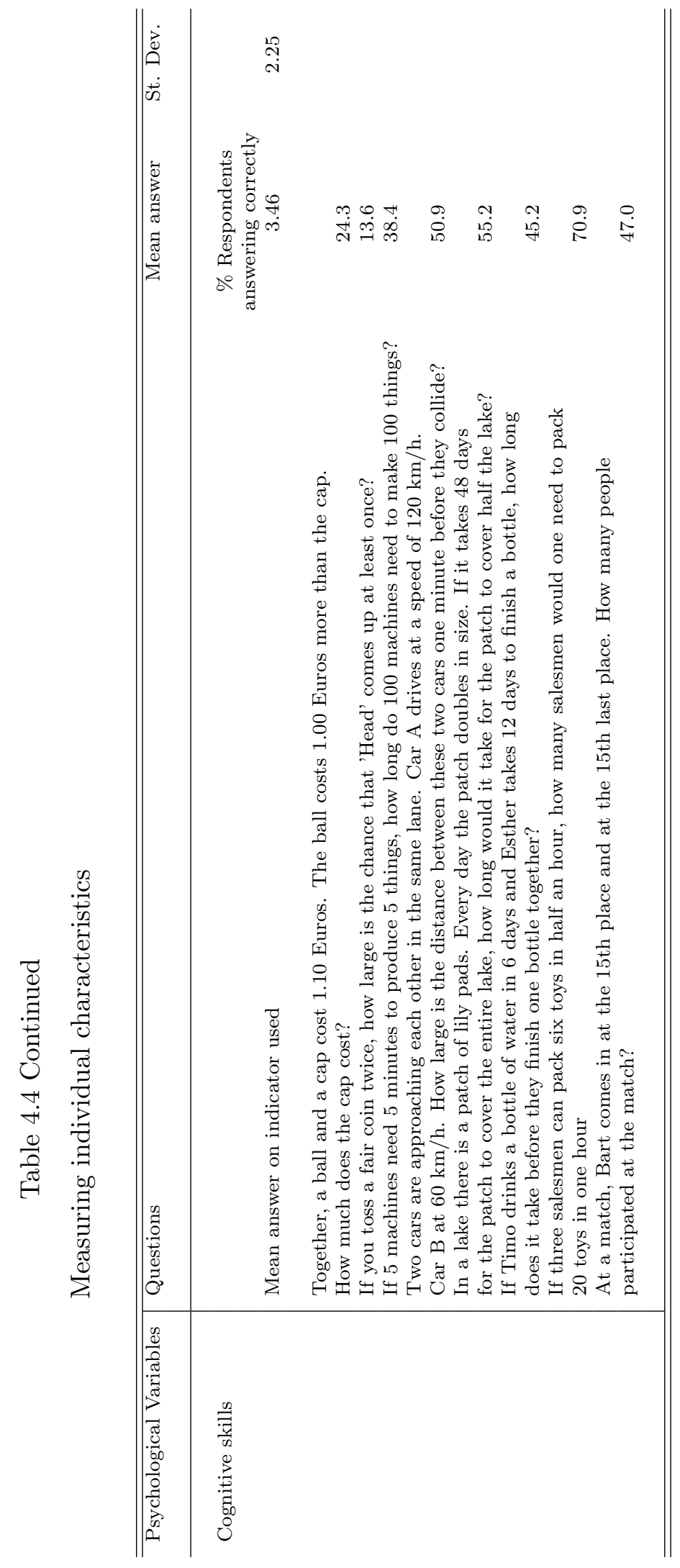


Table 5: Correlations between measures of personal characteristics

\begin{tabular}{l|ccccc}
\hline \hline & Time preference & Cognitive skills & Anxiety & Imagination & Risk aversion \\
Time preference & 1.000 & -0.036 & -0.015 & $-0.081^{* * *}$ & $-0.052^{* *}$ \\
Cognitive skills & & 1.000 & $-0.094^{* * *}$ & 0.030 & $-0.095^{* * *}$ \\
Anxiety & & & 1.000 & $-0.066^{* * *}$ & $0.089^{* * *}$ \\
Imagination & & & & 1.000 & 0.021 \\
Risk aversion & & & & \\
& & & & 1.000 \\
\hline \hline
\end{tabular}

Source: Research Centre for Education and the Labour Market 2005 graduate survey supplement. $* \mathrm{p}<0.10, * * \mathrm{p}<0.05, * * * \mathrm{p}<0.01$.

Table 5 shows the correlation between the measures. The table indicates that time preference is related negatively with imagination and risk aversion. Cognitive skills are related negatively with anxiety and risk aversion. More anxiety is related with less imagination and more risk aversion.

\section{Method}

We use a ranked-order logit regression. ${ }^{4}$ This is a system of the following simultaneously estimated equations:

$$
\begin{aligned}
Y_{E} & =\alpha_{1} * E+\alpha_{2} * D_{i E}+\alpha_{3} * S D_{i E}+\alpha_{4} *(S D * D)_{i E}+\varepsilon_{i E} \\
Y_{E W} & =\beta_{1} * E W+\alpha_{2} * D_{i E W}+\alpha_{3} * S D_{i E W}+\alpha_{4} *(S D * D)_{i E W}+\varepsilon_{i E W} \\
Y_{T W} & =\gamma_{1} * T W+\alpha_{2} * D_{i T W}+\alpha_{3} * S D_{i T W}+\alpha_{4} *(S D * D)_{i T W}+\varepsilon_{i T W} \\
Y_{M T} & =\delta_{1} * M t+\alpha_{2} * D_{i M T}+\alpha_{3} * S D_{i M T}+\alpha_{4} *(S D * D)_{i M T}+\varepsilon_{i M T} \\
Y_{C} & =\zeta_{1} * C+\alpha_{2} * D_{i C}+\alpha_{3} * S D_{i C}+\alpha_{4} *(S D * D)_{i C}+\varepsilon_{i C} \\
Y_{S M} & =\eta_{1} * S M+\alpha_{2} * D_{i S M}+\alpha_{3} * S D_{i S M}+\alpha_{4} *(S D * D)_{i S M}+\varepsilon_{i S M}
\end{aligned}
$$

in which $Y$ is a latent variable describing the preference for a course (estimated by a dummy variable with the value 1 if the course is chosen and 0 if it is not chosen), $E$ stands for English, $E W$ for Efficient working, $T W$ for Team work, $M T$ for Management,

\footnotetext{
${ }^{4}$ See for a comprehensive overview of this method Allison and Christakis (1994).
} 
$C$ for Computer skills, and $S M$ for Stress management. $D_{i E}$ is a dummy for whether English is the default for individual $i, S D_{i E}$ is the skill-deficiency of person $i$ in English. To estimate whether courses related to topics in which the respondent has a skill-deficiency are chosen more often if offered in the default package we include for each course a cross effect of the skill-deficiency and the default: $(S D * D)$.

The three courses with the highest $Y$ are chosen. Note first that by having the same parameters per variable for the different courses, we assume that the effect of the variables on the preference for the course will be the same across courses. ${ }^{5}$ Secondly, because we are measuring within person differences, we do not include separate individual characteristics. In an extension of the model, we do include however interactions of these characteristics with the variables of interest. $D, S D$, and $S * S D$ are then replaced respectively by:

$$
\begin{aligned}
D_{i c} & =\beta_{0}+\sum_{1}^{k} \beta_{k} * D_{i c} * \psi_{i k}+\varepsilon_{i c} \\
S D_{i c} & =\beta_{0}+\sum_{1}^{k} \beta_{k} * S D_{i c} * \psi_{i k}+\varepsilon_{i c} \\
(S D * D)_{i c} & =\beta_{0}+\sum_{1}^{k} \beta_{k} *(S D * D)_{i c} * \psi_{i k}+\varepsilon_{i c}
\end{aligned}
$$

in which $c$ is a vector of courses, and $\psi$ are individual characteristics.

\section{Results}

Table 6 shows the main results of our analysis. First, we only include the default and the skill-deficiency variable in a regression. We find that people choose to reduce their skill-deficiencies and that their choice is largely driven by the default option. Concerning the size of the coefficients, we find that if a course is included in the default package, the probability that the course is chosen increases by $25.7 \%$ relative to another otherwise equally attractive course. ${ }^{6}$ A 1-point increase in the skill-deficiency increases the chance of choosing the course by $6.3 \%$.

\footnotetext{
${ }^{5}$ In the robustness analysis, we drop this assumption.

${ }^{6}$ This result is obtained by multiplying the coefficient with $0.5(1-0.5)$.
} 
Table 6: Default, skill-deficiency and the choice for courses

\begin{tabular}{|c|c|c|c|c|}
\hline Default $^{a}$ & $\begin{array}{c}\text { Model } 1 \\
1.029^{* * *} \\
(0.040)\end{array}$ & $\begin{array}{c}\text { Model } 2 \\
0.971^{* * *} \\
(0.044)\end{array}$ & $\begin{array}{c}\text { Model } 3 \\
1.029^{* * *} \\
(0.040)\end{array}$ & $\begin{array}{c}\text { Model } 4 \\
1.637^{* * *} \\
(0.180)\end{array}$ \\
\hline Skill-deficiency & $\begin{array}{l}0.250^{* * *} \\
(0.042)\end{array}$ & $\begin{array}{c}0.099 \\
(0.061)\end{array}$ & & \\
\hline Default*Skill-deficiency & & $\begin{array}{l}0.266^{* * *} \\
(0.077)\end{array}$ & & \\
\hline Own level & & & $\begin{array}{c}-0.217^{* * *} \\
(0.030)\end{array}$ & $\begin{array}{c}-0.044 \\
(0.046)\end{array}$ \\
\hline Required level & & & $\begin{array}{l}0.117^{* * *} \\
(0.024)\end{array}$ & $\begin{array}{c}0.046 \\
(0.036)\end{array}$ \\
\hline Default*Own level & & & & $\begin{array}{c}-0.274^{* * *} \\
(0.054)\end{array}$ \\
\hline Default*Required level & & & & $\begin{array}{l}0.113^{* * *} \\
(0.043)\end{array}$ \\
\hline Dummies per course & Incl. & Incl. & Incl. & Incl. \\
\hline
\end{tabular}

Source: Research Centre for Education and the Labour Market 2005 graduate survey supplement.

$* \mathrm{p}<0.10, * * \mathrm{p}<0.05, * * * \mathrm{p}<0.01$

\footnotetext{
${ }^{a}$ The experiment to measure the choice for courses reads as follows: Suppose your work has a new settlement in which everyone can participate during working hours in the following courses, the expenses of which are fully covered by the employer: English, Computer skills, Stress Management. However, it is also possible to exchange one or more courses. The alternatives are Management skills, Team work, Efficient working. Do you choose the suggested set of courses or do you want to exchange? We randomized the offered courses and alternatives. We analyze the effect of having a specific course offered to a person by default on the choice for this course.
}

When we include the interaction of the skill-deficiency with the default in the regression to analyze whether topics in which the respondent has a skill-deficiency are chosen more often if offered in the default package, we find that the effect of the skill-deficiency is completely taken over by the interaction variable. Therefore, workers generally do not have the propensity to choose courses with which they can reduce job related skillshortages. However, workers choose courses which reduce their skill-deficiency more often if these courses are in the default package.

To analyze which component of the skill-deficiency drives the result, we separate this variable in the skills possessed and the skills required. We find that people invest less in the skills they already have and more in skills they still need at their jobs. Interestingly, the coefficient of the own skills is about double the size of the coefficient of the required skills. This might indicate that people are investing more in general skills than in job-specific skills. Adding the interaction with the default, we find similarly that the interaction term with the default is significant for both own skills and required skills, while the separate variables own skills and required skills are not significant. 


\subsection{Individual attributes}

An interesting question is which people react more to a course being in the default set, and which people invest more in their skill-deficiency. Table 7 shows the interactions of personal characteristics with the default and the skill-deficiency variables.

We find that workers who are have a more developed capacity to imagine the future invest more in their skill-deficiencies. Imagination is the only personal attribute which is related with the skill-deficiency.

Better imagination also increases the probability of making a deliberate choice. We find that lower anxiety, lower risk aversion, and more cognitive skills also increase the probability of a deliberate choice, but these attributes are not related with investments in the skill-needs of the respondent.

The relations between these characteristics and the choice for the default or the skilldeficiency reduction are plausible. At the minimum, this may serve as a validation of the methodology we followed to measure the investment decisions. Next to this, we may conclude from these findings that especially the power to imagine the future is an important characteristic related to investing in courses that reduce skill-deficiencies.

\section{Robustness}

\subsection{Linearity assumption of skill-deficiency variable}

In the analysis, a negative skill-deficiency (i.e. skill abundancy) is recoded to zero skilldeficiency and we assume a linear relation between the skill-deficiency and the choice for the course. To investigate whether the results differ if we did not recode negative values and if we dropped the assumption of linearity of the skill deficiency variable, we do not recode to zero and break up the skill-deficiency variable into separate dummies for each of its levels, i.e. we regress the likelihood of choosing a course on whether the course is in the default set, dummies for the level of the skill gap and interactions of the default and these dummies. The skill deficiency level -4 is left out as a reference category. Graph 1 shows the coefficients of the dummies for the skill deficiencies. Few people indicate to have a skill-deficiency level 3. If we exclude this level, we can see that there is no significant difference in the size of the coefficients. Graph 2 shows that for 
Table 7: Psychological attributes and the choice for the default and skill deficiency

\begin{tabular}{|c|c|}
\hline \\
\hline Constant & $\begin{array}{l}1.104^{* * *} \\
(0.279)\end{array}$ \\
\hline Anxiety & $\begin{array}{l}0.097^{* * *} \\
(0.036)\end{array}$ \\
\hline Cognitive skills & $\begin{array}{c}-0.049^{* * *} \\
(0.017)\end{array}$ \\
\hline Time preference & $\begin{array}{c}0.254 \\
(0.231)\end{array}$ \\
\hline Imagination & $\begin{array}{c}-0.136^{* * *} \\
(0.044)\end{array}$ \\
\hline Risk Aversion & $\begin{array}{l}0.003^{* * *} \\
(0.001)\end{array}$ \\
\hline Skill-deficiency model & \\
\hline Constant & $\begin{array}{r}-0.578 \\
(0.449)\end{array}$ \\
\hline Anxiety & $\begin{array}{c}0.006 \\
(0.054)\end{array}$ \\
\hline Cognitive skills & $\begin{array}{c}-0.003 \\
(0.027)\end{array}$ \\
\hline Time preference & $\begin{array}{c}0.420 \\
(0.365)\end{array}$ \\
\hline Imagination & $\begin{array}{l}0.155^{* *} \\
(0.077)\end{array}$ \\
\hline Risk Aversion & $\begin{array}{c}-0.002 \\
(0.002)\end{array}$ \\
\hline Default ${ }^{*}$ Skill-deficiency model & \\
\hline Constant & $\begin{array}{c}0.367 \\
(0.578)\end{array}$ \\
\hline Anxiety & $\begin{array}{c}0.079 \\
(0.071)\end{array}$ \\
\hline Cognitive skills & $\begin{array}{c}-0.007 \\
(0.035)\end{array}$ \\
\hline Time preference & $\begin{array}{c}-0.582 \\
(0.468)\end{array}$ \\
\hline Imagination & $\begin{array}{r}-0.036 \\
(0.097)\end{array}$ \\
\hline Risk Aversion & $\begin{array}{c}-0.001 \\
(0.002)\end{array}$ \\
\hline Dummies per course & Incl. \\
\hline
\end{tabular}

Source: Research Centre for Education and the Labour Market 2005 graduate survey supplement. $* \mathrm{p}<0.10, * * \mathrm{p}<0.05, * * * \mathrm{p}<0.01$ 
Figure 1: Regression coefficients of dummies per skill-deficiency level

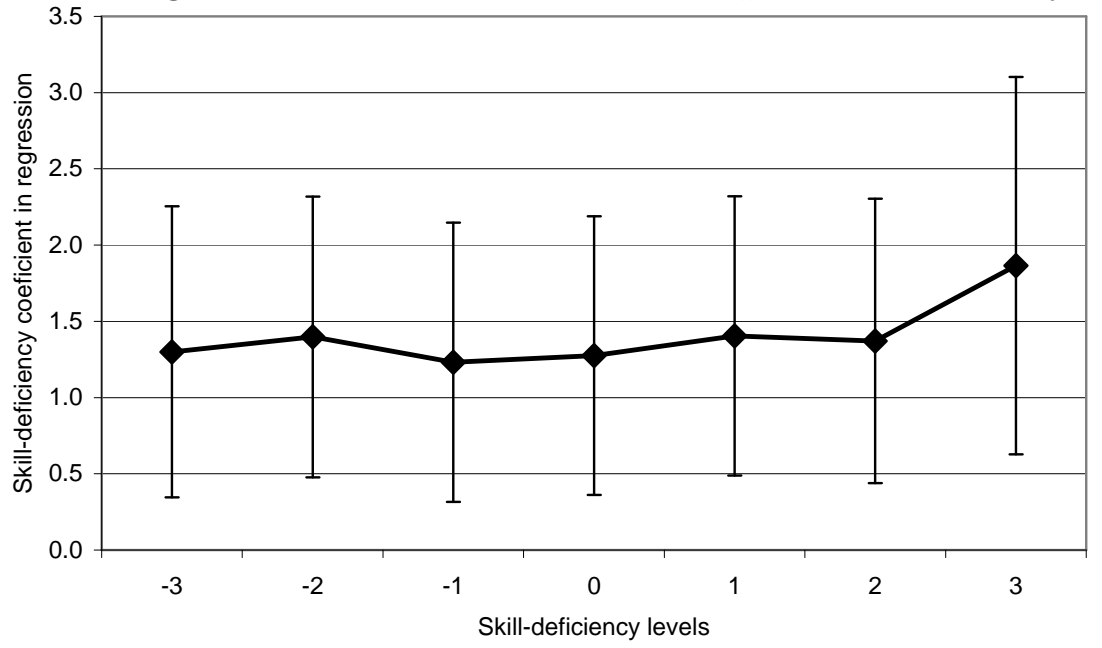

Source: Research Centre for Education and the Labour Market 2005 graduate survey supplement.

the interaction between the default and the dummies for the skill deficiencies, we find an approximately linear upward trend. These two results validate the assumption of linearity in the skill deficiency variable in the analysis and show that including negative values of the skill-deficiency variable would not lead to qualitatively different results. ${ }^{7}$

\subsection{Selection bias}

Another concern could be that selection bias drives the results. People who are less ambitious may self-select into jobs which require less skills. They therefore may have less skill-deficiencies and are less required to invest in their skill-needs. In our survey, there are two variables which may serve as proxies for ambition. The first is the question "With respect to your job, indicate to which extent challenge is important to you," and the second is the question "With respect to your job, indicate to which extent career perspectives are important to you." The answer categories to both questions are on a 1-5 scale, 1 being "irrelevant," and 5 being "very important." Table 8 shows the answers to this question. The table shows that almost all respondents value challenge and career perspectives highly. Challenge is valued by nearly all respondents as high (4) or very high

\footnotetext{
${ }^{7}$ If we do not recode the negative values of the skill-deficiency to zero, we find that the interaction of the default and the skill-deficiency variable remains positive and significant at the $5 \%$ level (coef: .115, st.err. 0.054). The skill-deficiency variable is still not significantly different from zero, and the default variable remains significantly larger than zero (coefficient: 1.002, st.err. 0.055). If we interact the default and the dummies for the skill-deficiency with individual attributes, we find similar results as in the main analysis.
} 
Figure 2: Regression coefficients of the interaction of the default with dummies per skilldeficiency level

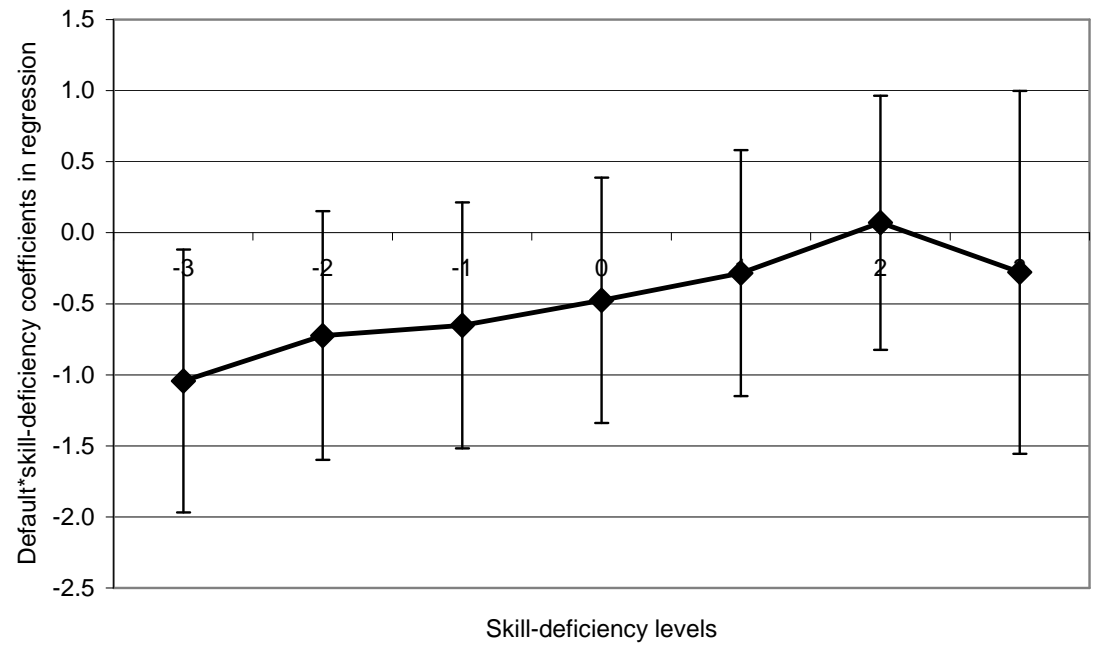

Source: Research Centre for Education and the Labour Market 2005 graduate survey supplement.

Table 8: Attitudes related to work

\begin{tabular}{l|lrrrrrrr}
\hline \hline Work Attitudes & \multicolumn{1}{|l}{ Irrelevant } & & & & Very important & Total & Mean $^{a}$ & St.Dev. \\
& & & & & & & & \\
Challenge & 0.1 & 0.3 & 3.6 & 40.4 & 55.6 & 100 & 4.51 & 0.59 \\
Career perspective & 1.0 & 4.8 & 21.0 & 45.1 & 28.2 & 100 & 3.95 & 0.88 \\
& & & & & & & & \\
\hline \hline
\end{tabular}

Source: Research Centre for Education and the Labour Market 2005 supplement.

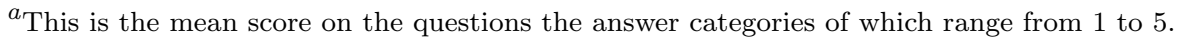

(5), while career perspective is valued on average less highly than challenge.

We separate the group that has lower ambition from those that have higher ambition based on these two variables. Low ambition is defined as scoring 4 or less on the challenge question. In the second analysis, low ambition is defined as 3 or less on the career perspective question. Table 9 and 10 show that in the two analyses, the results are similar for both people with high and low ambition. Both groups invest significantly in their deficiencies if a related course is offered to them by default. In both groups, the choices are substantially driven by the default option. Interestingly, we find with both ambition proxies that the interaction of the default and the skill-deficiency has a slightly higher coefficient for the group with lower ambition. This suggests that people in lower level jobs are not lazy or uninterested in their future career, but are willing to invest in 
Table 9: Default, skill-deficiency and the choice for courses for different values attached to challenge in job

\begin{tabular}{|c|c|c|c|c|}
\hline & \multicolumn{2}{|c|}{ Highly values challenge in job } & \multicolumn{2}{|c|}{ Values challenge in job less } \\
\hline Default & $\begin{array}{c}\text { Model } 1 \\
0.977^{* * *} \\
(0.053)\end{array}$ & $\begin{array}{c}\text { Model } 2 \\
0.927^{* * *} \\
(0.057)\end{array}$ & $\begin{array}{l}\text { Model } 1 \\
1.077^{* * *} \\
(0.059)\end{array}$ & $\begin{array}{c}\text { Model } 2 \\
1.008^{* * *} \\
(0.063)\end{array}$ \\
\hline Skill-deficiency & $\begin{array}{l}0.228^{* * *} \\
(0.054)\end{array}$ & $\begin{array}{c}0.101 \\
(0.078)\end{array}$ & $\begin{array}{l}0.254^{* * *} \\
(0.061)\end{array}$ & $\begin{array}{c}0.060 \\
(0.093)\end{array}$ \\
\hline Default*Skill-deficiency & & $\begin{array}{l}0.227^{* *} \\
(0.097)\end{array}$ & & $\begin{array}{l}0.337^{* * *} \\
(0.117)\end{array}$ \\
\hline Dummies per course & Incl. & Incl. & Incl. & Incl. \\
\hline
\end{tabular}

Source: Research Centre for Education and the Labour Market 2005 graduate survey supplement. $* \mathrm{p}<0.10, * * \mathrm{p}<0.05, * * * \mathrm{p}<0.01$

Table 10: Default, skill-deficiency and the choice for courses for different values attached to career perspectives

\begin{tabular}{l|cccc}
\hline \hline & Highly values career perspectives & Values career perspectives less \\
& & & \\
& Model 1 & Model 2 & Model 1 & Model 2 \\
Default & $1.004^{* * *}$ & $0.954^{* * *}$ & $1.085^{* * *}$ & $1.016^{* * *}$ \\
& $(0.046)$ & $(0.050)$ & $(0.075)$ & $(0.081)$ \\
Skill-deficiency & $0.266^{* * *}$ & $0.130^{*}$ & $0.229^{* * *}$ & 0.061 \\
& $(0.049)$ & $(0.072)$ & $(0.073)$ & $(0.111)$ \\
Default*Skill-deficiency & & $0.243^{* * *}$ & & $0.280^{* *}$ \\
& & $(0.091)$ & & $(0.134)$ \\
Dummies per course & Incl. & Incl. & Incl. & \\
\hline \hline
\end{tabular}

Source: Research Centre for Education and the Labour Market 2005 graduate survey supplement. $* \mathrm{p}<0.10, * * \mathrm{p}<0.05, * * * \mathrm{p}<0.01$

their skill-deficiencies.

\subsection{Incentives to invest per course}

For the average skill, people invest in their deficiencies if a course related to the skill is offered to them by default. An interesting question is whether this effect is similar across the six courses.

Table 11 reports the findings for the separate skills. We find for all skills that if a course related to the skill is offered in the default, it is chosen more often.

With respect to the skill-deficiency variable, we find that a higher skill-deficiency in a course does not induce people to invest in the course in a similar way. English, Stress management and Computer skills are chosen if the deficiency in these skills is larger, while 
Table 11: Analysis per course

\begin{tabular}{|c|c|}
\hline Default*English & $\begin{array}{l}1.551^{* * *} \\
(0.179)\end{array}$ \\
\hline Default*Stress management & $\begin{array}{l}1.586^{* * * *} \\
(0.166)\end{array}$ \\
\hline Default*Computer skills & $\begin{array}{l}0.608^{* * *} \\
(0.141)\end{array}$ \\
\hline Default*Team work & $\begin{array}{l}1.194^{* * *} \\
(0.132)\end{array}$ \\
\hline Default*Efficient working & $\begin{array}{l}0.562^{* * *} \\
(0.104)\end{array}$ \\
\hline Default*Management & $\begin{array}{l}0.594^{* * *} \\
(0.139)\end{array}$ \\
\hline Skill-deficiency*English & $\begin{array}{l}0.749^{* * *} \\
(0.247)\end{array}$ \\
\hline Skill-deficiency*Stress management & $\begin{array}{l}0.491^{* *} \\
(0.201)\end{array}$ \\
\hline Skill-deficiency*Computer skills & $\begin{array}{c}0.345^{*} \\
(0.176)\end{array}$ \\
\hline Skill-deficiency*Team work & $\begin{array}{c}0.037 \\
(0.154)\end{array}$ \\
\hline Skill-deficiency*Efficient working & $\begin{array}{c}0.127 \\
(0.130)\end{array}$ \\
\hline Skill-deficiency*Management & $\begin{array}{r}-0.142 \\
(0.091)\end{array}$ \\
\hline Default*Skill-deficiency*English & $\begin{array}{c}-0.346 \\
(0.269)\end{array}$ \\
\hline Default*Skill-deficiency*Stress management & $\begin{array}{c}-0.009 \\
(0.221)\end{array}$ \\
\hline Default*Skill-deficiency*Computer skills & $\begin{array}{l}0.718^{* *} \\
(0.290)\end{array}$ \\
\hline Default*Skill-deficiency*Team work & $\begin{array}{c}0.585 * \\
(0.321)\end{array}$ \\
\hline Default*Skill-deficiency*Efficient working & $\begin{array}{c}-0.030 \\
(0.159)\end{array}$ \\
\hline Default*Skill-deficiency*Management & $\begin{array}{l}0.589^{* *} \\
(0.241)\end{array}$ \\
\hline Dummies per course & Incl. \\
\hline
\end{tabular}

Source: Research Centre for Education and the Labour Market 2005 graduate survey supplement. $* \mathrm{p}<0.10, * * \mathrm{p}<0.05, * * * \mathrm{p}<0.01$

people choose courses to reduce their skill-deficiency in Computer skills, Team work and Management if these courses are offered to them by default. A higher skill-deficiency in Efficient working is not related to a higher choice for this course.

These results may indicate that people are more able to see the benefits of investing in English and Stress management skills themselves, while the benefits of investing in Team work and Management skills become apparent to them only when their attention is drawn to these skills by their manager. A reason for this may be that English and Stress Management are skills which relate more to personal needs, while Team work and Management relate more to interpersonal skills. 


\section{Conclusions}

We argue that individuals differ in their interest and ability to choose courses and that individual attributes determine the return on the investment in training. We analyze which people choose courses to reduce work-related skill-deficiencies, and who chooses courses deliberately. To control for differences with respect to opportunities to participate in courses, we use an experiment in which graduates hypothetically have to choose courses. They either accept a randomly designed (default) package of courses or exchange courses from the package with other randomly assigned courses. We relate their choices to an earlier survey in which they were asked to rate their skill-level and the required skill-level at their jobs with respect to the aspects. Moreover, we measure several individual attributes. We find that in general, people do not seem to choose courses to reduce their skill-deficiencies. However, workers choose courses which reduce their skill-deficiency more often if these courses are in the default package. Our estimates therefore suggest that managers and training specialists can have an important role in an efficient development of workers' human capital. Relating choice behavior to personal characteristics, we find evidence that people with a better developed imagination invest more in their skill-deficiencies and make more independent choices.

\section{References}

Abadie, A., And S. GAY (2006): "The Impact of Presumed Consent Legislation on Cadaveric Organ Donation: A Cross Country Study," Journal of Health Economics, 25(4), 599-620.

Allison, P. D., and N. A. Christakis (1994): "Logit Models for Sets of Ranked Items," Sociological Methodology, 24, 199-228.

Bowles, S., H. Gintes, And M. Osborne (2001): "The Determinants of Earnings: A Behavioral Approach," Journal of Economic Literature, 39(4), 1137-1176.

Choi, J., D. Laibson, B. Madrian, and A. Metrick (2005): "Optimal Defaults and Active Decisions," NBER Working Paper No. 11074.

Colquitt, J., J. LePine, And R. Noe (2000): "Towards an Integrative Theory of 
Training Motivation: A Meta-Analytic Path Analysis of 20 Years of Research," Journal of Applied Psychology, 85(5), 678-707.

Conti, G. (2005): "Training, Productivity and Wages in Italy," Labour Economics, $12(4), 557-576$.

Eraut, M. (2000): "Non-Formal Learning and Tacit Knowledge in Professional Work," British Journal of Educational Psychology, 70(1), 113-136.

FIELD, J. (2000): Lifelong Learning and the New Educational Order. Trentham Books, Stoke on Trent.

Frazis, H., And M. A. Loewenstein (2005): "Reexamining the Returns to Training; Functional Form, Magnitude, and Interpretation," Journal of Human Resources, 40(2), 453-476.

Frederick, S. (2005): "Cognitive Reflection and Decision Making," Journal of Economic Perspectives, 19(4), 25-42.

Frederick, S., G. Loewenstein, and T. O’Donogue (2002): "Time Discounting and Time Preference: A Critical Review," Journal of Economic Literature, XL, 351401.

Heckman, J., J. Stixrud, and S. Urzua (2006): "The Effects of Cognitive and Noncognitive Abilities on Labor Market Outcomes and Social Behavior," Journal of Labor Economics, 24(3), 411-482.

Johnson, E., S. Bellman, and G. Lohnse (2002): "Defaults, Framing and Privacy: Why Opting In-Opting Out," Marketing Letters, 13(1), 5-15.

Johnson, E., And D. Goldstein (2003): "Do Defaults Save Lifes?," Science, 302, $1338-1339$.

Johnson, E., J. Hershey, J. Meszaros, and H. Kunreuther (1993): "Framing, Probability Distortions, and Insurance Decisions," Journal of Risk and Uncertainty, $7(1), 35-53$. 
Mueser, P. R. (1979): "The Effects of Noncognitive Traits," in Who Gets Ahead? The Determinants of Economic Success in America, ed. by C. Jencks, pp. 122-158. New York: Basic Books.

Parent, D. (1999): "Wages and Mobility: The Impact of Employer-Provided Training," Journal of Labor Economics, 17(2), 298-317.

Park, C., S. Yun, And D. MacInnis (2000): "Choosing What I want Versus Rejecting What I Do Not Want: An Application of Decision Framing to Product Option Choice Decisions," Journal of Marketing Research, 37(2), 187-202.

Rachlin, H., A. Raineri, and D. Cross (1991): "Subjective Probability and Delay," J. Exp. Anal. Behav., 55, 233-244.

Sargant, N., and F. Aldridge (2002): Adult Learning and Social Division: A Persistent Pattern, Vol. 1. NIACE, Leicester.

Shields, M. (1998): "Changes in the Determinants of Employer-Funded Training for Full-Time Employees in Britain," Oxford Bulletin of Economics and Statistics, 60, 189214 . 